\section{US AIDS education programme on-again, off-again}

\section{Washington}

Plans for a coordinated, multi-agency education campaign next month aimed at slowing the spread of AIDS (acquired immune deficiency syndrome) are in disarray. Public service announcements await approval, publicity for the campaign has been muted and a national mailing of an information brochure has been scrapped. But the Centers for Disease Control (CDC) are pushing for an "AIDS Prevention Month", despite conflicting signals on how to proceed from the highest levels of government.

CDC director James Mason described some of his agencies' plans to the presidential AIDS panel that last week held its first meeting (see right). The CDC campaign's theme is "America responds to AIDS", and will involve government agencies working in partnership with state, local and private groups already coping with the AIDS pandemic. CDC is also sponsoring forums to discuss how to make these efforts more successful. Five cities will receive a heightened level of attention, including underwriting for television programmes, information desks in pharmacies and more intensive public relations campaigns.

But as initially conceived, CDC's activities were only one part of a governmentwide education effort. Paula Van Ness, director of the national AIDS information programme at CDC, says an educational brochure was to be mailed to every US home as part of the month-long education blitz. But a decision to go ahead with the mailing failed to materialize, despite the fact that Congress had appropriated some $\$ 20$ million to cover the cost of the campaign. That money must be spent before 30 September, the end of the current fiscal year, or Congress must give its permission to use it for something else. The administration is currently debating an alternative method for distributing the brochure, targeting groups with a special need for education. The issue of whether to mail the brochure was on the agenda of the presidential AIDS panel, but was removed at the last minute.

Robert Sweet of the Domestic Policy Council says plans for a national mailing have been on hold for some time, pending the outcome of a national survey being conducted by the National Center for Health Statistics (NCHS) to assess the public's knowledge and attitudes toward AIDS. Beginning in August, a series of questions was added to the National Health Interview Study - a 30-year-old continuing survey on various health topics - to determine what Americans already know about AIDS. Each week, some
1,000 households are surveyed, with an 88 per cent response rate so far. The first published data are expected in November, but Owen Thornberry of the NCHS says two-thirds of respondents have indicated they would be willing to donate blood for the national random AIDS antibody test being planned by CDC. The NCHS survey will be used to determine the effectiveness of government education campaigns.

The October AIDS Prevention Month is one of the first major campaigns whose effects are expected to show up in the survey. Although plans are still being formulated, CDC is working on 31 events - one for each day of the month - with different organizations around the country. But in every case, the events have been planned with a host group that can continue the event if $\mathrm{CDC}$ is instructed to call off their plans. Chuck Klein, a spokesman for the Department of Health and Human Services (HHS), says that if Congress declares October national AIDS awareness month, HHS will join in with enthusiasm. HHS Secretary Otis Bowen has recorded a series of public service announcements about AIDS, and the department is negotiating with the National Association of Broadcasters to present a multi-part radio programme on stations throughout the country.

Another problem frustrating government-sponsored education plans is the inability to purchase advertising time during prime viewing hours. The government has contracted with one of the largest US advertising agencies, Ogilvy and Mather, to help develop an advertising campaign. Klein says government agencies are prohibited from purchasing television time with only a few exceptions - the annual \$155-million advertisement campaign for armed forces recruits being the most notable. But the government could find ways around this restriction - soliciting a non-governmental co-sponsor — and Congress has been willing to amend laws to allow AIDS education plans to proceed.

The "National AIDS Awareness Test" broadcast on television stations nationwide on Tuesday evening this week was not encumbered by the laws restricting government advertising. It was sponsored by the Metropolitan Life insurance company The hour-long show had a questionand-answer format, with answer forms printed in programming guides so viewers could record and check their scores. The show featured Surgeon General C. Everett Koop, and other prominent public health and medical officials, so the government's educational agenda was well represented.

Joseph Palca \& Carol Ezzell
AIDS clashes in presidential commission

\section{Washington}

GAY activists, government agency officials, special interest groups, and health officials clashed last week at the first meeting of the US Presidential Commission on the HIV Epidemic, named after the virus that causes AIDS (acquired immune deficiency syndrome). The panel heard how the Public Health Service and other federal agencies are combating the AIDS pandemic, but they also listened to testimony suggesting that the government is not doing enough to counter the crisis, and that federal efforts are disjointed and suffer from credibility problems.

The AIDS commission has been under fire since its formation by presidential order in June (see Nature 328, 366 and 372 ; 1987) for lack of scientific expertise, and for the social and moral views of some of its members. Speaking before the panel, Otis Bowen, Secretary of Health and Human Services, defended the commission, adding that "constant criticism that this government is not doing enough is unfair and unwarranted".

Surgeon General C. Everett Koop told the commission of his concern about discrimination against patients with AIDS. Koop had strong words for doctors and other health professionals who refuse to treat AIDS patients, saying their attitudes threaten the basic assumption in medicine that health care should be available to anyone who needs it.

A parade of agency chiefs and department heads described to the panel the spectrum of federal activities to prevent the spread of HIV while preserving the rights of those already infected. At the end of the presentations, panel member William Walsh, founder of Project HOPE, pointed out that many federal programmes seemed to overlap, particularly in the area of educational campaigns. When he asked Ralph Bledsoe of the White House Domestic Policy Council why there seemed to be a lack of coordination between the efforts of different agencies, Bledsoe replied, "welcome to the federal government"

The commission has much to do before it prepares its preliminary report in December, and its final recommendations to the president by next September. Commission chairman Eugene Mayberry, head of the Mayo Foundation, urged the press and the public not to "make too much of controversial issues until we've had a chance to prepare". The commission is scheduled to meet in New York, San Francisco and Nashville during the next year.

Carol Ezzell 